\title{
The Pain Academy: An evaluation of a primary care brief psychoeducational program for persistent pain
}

\author{
Travis Cos $^{1}$, Venise Salcedo ${ }^{2}$, Alan Ford ${ }^{3}$, Michael Halpern ${ }^{2}$, and Diana Harris ${ }^{1}$ \\ ${ }^{1}$ Public Health Management Corporation \\ ${ }^{2}$ Temple University \\ ${ }^{3}$ Durham County Council
}

June 23, 2020

\begin{abstract}
Persistent pain affects $20 \%$ of adults and can impair one's daily functioning and well-being. Psychoeducational group interventions can be effective in aiding pain management and coping strategies, however the time commitment for most evidence-based programs (10-20 hours) leads to access barriers and delivery challenges in primary care. A mixed-methods, program evaluation was conducted on a low intensity, three-session, manualized group pilot psychoeducational intervention in a primary care practice, emphasizing pain education, behavioral strategies, and pain-alleviating activities. Eighty-two percent of the clinic's panel of individuals with persistent pain $(\mathrm{N}=128)$ and being prescribed opioid pain medication attended at least one class ( $\mathrm{N}=105)$. Attendees experienced significant pre-post improvements in self-reported pain functioning and favorable satisfaction ratings by patients and medical staff. However only $51 \%$ attended all three groups, despite frequent class offerings and heavily encourage by the patient's medical providers. This study reviews the potential promise and limitations of a low-intensity, limited session pain group to aid pain-related functioning. Additional investigation is warranted to optimize participant attendance, group format and frequency, and outcome assessment.
\end{abstract}

The Pain Academy: An evaluation of a primary-care brief psychoeducational program for persistent pain.

Travis A. Cos

Public Health Management Corporation, Research \& Evaluation Group

1500 Market Street, Centre Square East, Suite 1500

Philadelphia, PA 19102

Travis.cos@gmail.com

Venise J. Salcedo

Temple University, College of Public Health

Philadelphia, PA

venisejsalcedo@gmail.com

Alan D. Ford

Durham County, Criminal Justice Resource Center

Durham, North Carolina 


\section{aford@dconc.gov}

Michael Halpern

Temple University, Department of Public Health

Philadelphia, PA

michael.halpern@nih.gov

Diana Harris

Public Health Management Corporation, Research \& Evaluation Group

Philadelphia, PA

diharris@phmc.org

Suggested Running Head:

Pain Academy

\section{Hosted file}

Pain Academy complete manuscript (Final and Masked).docx available at https://authorea.com/ users/336131/articles/461902-the-pain-academy-an-evaluation-of-a-primary-care-briefpsychoeducational-program-for-persistent-pain

\section{Hosted file}

Table 1- Pain Academy Program.docx available at https://authorea.com/users/336131/articles/ 461902-the-pain-academy-an-evaluation-of-a-primary-care-brief-psychoeducational-programfor-persistent-pain

\section{Hosted file}

Table 2- Pain Academy Measure.docx available at https://authorea.com/users/336131/articles/ 461902-the-pain-academy-an-evaluation-of-a-primary-care-brief-psychoeducational-programfor-persistent-pain

\section{Hosted file}

Table 3- Pain Academy Satisfaction.docx available at https://authorea.com/users/ 336131/articles/461902-the-pain-academy-an-evaluation-of-a-primary-care-briefpsychoeducational-program-for-persistent-pain

\section{Hosted file}

Table 4- Pain Academy Provider Impression.docx available at https://authorea.com/ users/336131/articles/461902-the-pain-academy-an-evaluation-of-a-primary-care-briefpsychoeducational-program-for-persistent-pain 


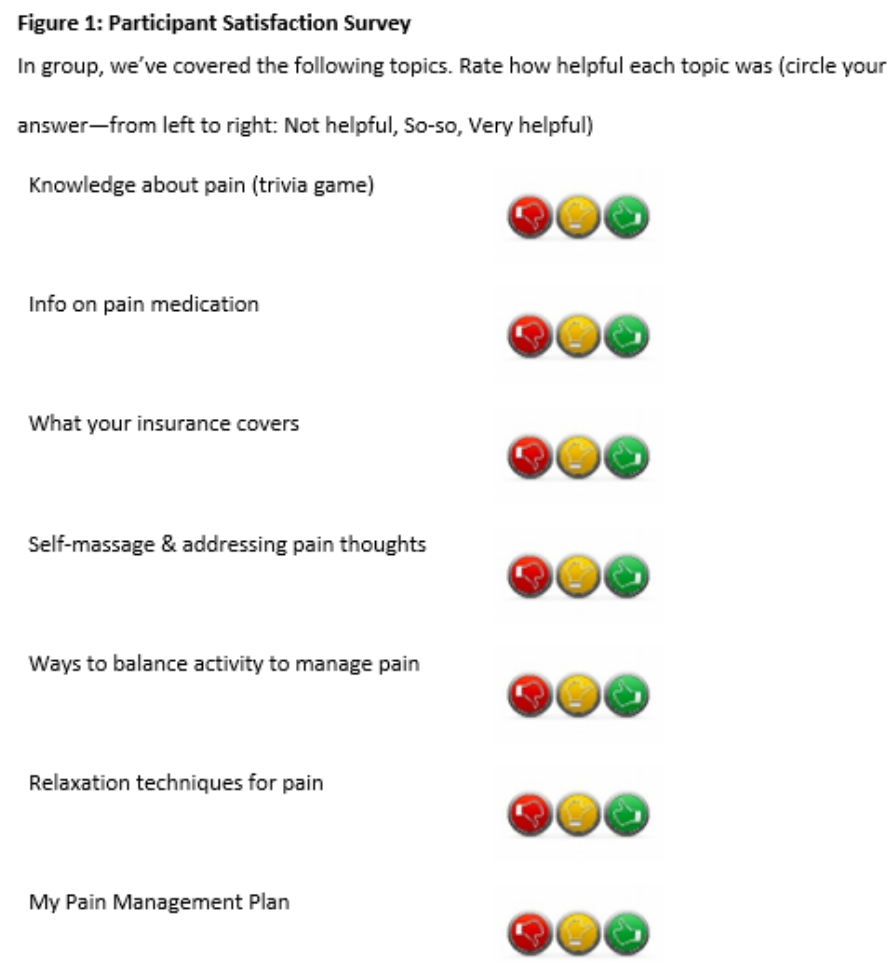

